\title{
Hand in the snow
}

\author{
Colleen Fitzpatrick \\ From 6th German Conference on Chemoinformatics, GCC 2010 \\ Goslar, Germany. 7-9 November 2010
}

As reported by MSNBC, CNN, and in newspapers worldwide:

On March 12, 1948, at 9:14 pm, Northwest Flight 4422 en route from Shanghai, China to La Guardia Airfield in New York, slammed into Mount Sanford, a 16,237 -foot high peak located in a remote area of Alaska, 200 miles northeast of Anchorage.

The 30 military personnel onboard, including six crew members and 24 merchant mariner passengers, were killed instantly. Nothing was done to recover the wreck. Because of its remote location, the crash site was abandoned, the debris digested within a few days by the active glacier into which it fell. It would take fifty years, and the efforts of two commercial airline pilots to reach the scene of the accident. It would take another ten years and a team of world class DNA experts, forensic genealogists, and fingerprint experts to identify the frozen human forearm and hand that was found by the pilots, well-preserved by the glacier for half a century.

By September 2008, 28 of the 30 passengers had been eliminated by DNA analysis, fingerprint matching, or both. Only two more passengers remained on the list, the two most difficult to locate family members for who could serve as references for DNA analysis.

Our search for the family of passenger No 29 was featured in newspapers around the world, including USA Today and the Washington Post. Francis J Van Zandt was born in 1911 in Vermont, the son of a father from upstate New York and a mother who was an obscure Irish immigrant named Margaret Conway. This lecture describes how we achieved the impossible and found a DNA match for the arm and hand in the snow, finally laying to rest the 30 victims of Northwest Flight 4422.

Published: 19 April 2011

Correspondence: colleen@forensicgenealogy.info

Huntington Beach, CA, USA
doi:10.1186/1758-2946-3-S1-01

Cite this article as: Fitzpatrick: Hand in the snow. Journal of

Cheminformatics 2011 3(Suppl 1):01.

\section{Publish with ChemistryCentral and every scientist can read your work free of charge \\ "Open access provides opportunities to our colleagues in other parts of the globe, by allowing anyone to view the content free of charge." \\ W. Jeffery Hurst, The Hershey Company. \\ - available free of charge to the entire scientific community \\ - peer reviewed and published immediately upon acceptance \\ - cited in PubMed and archived on PubMed Central \\ - yours - you keep the copyright \\ Submit your manuscript here: \\ http://www.chemistrycentral.com/manuscript/

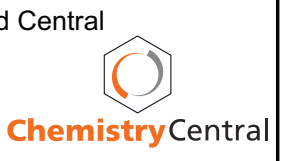

